\title{
Isolation and identification of avirulent strains of Bacillus anthracis from environmental samples in Central Java, Indonesia
}

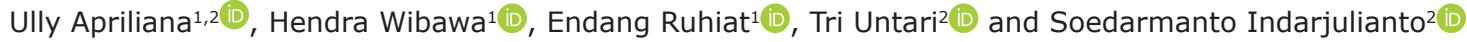

1. Disease Investigation Center Wates, Jalan Raya Jogja-Wates Km 27 Po Box 18, Wates, Yogyakarta, 55602, Indonesia; 2. Department of Internal Medicine, Faculty of Veterinary Medicine, Universitas Gadjah Mada, Jl. Fauna 2, Karangmalang, Yogyakarta, 55281, Indonesia.

Corresponding author: Soedarmanto Indarjulianto, e-mail: indarjulianto@ugm.ac.id Co-authors: UA: ullyindah82@mail.ugm.ac.id, HW: hi.wibawa@gmail.com, ER: endru284@gmail.com, TU: t untari@ugm.ac.id

Received: 29-04-2021, Accepted: 23-08-2021, Published online: 13-10-2021

doi: www.doi.org/10.14202/IJOH.2021.204-211 How to cite this article: Apriliana U, Wibawa H, Ruhiat E, Untari T, Indarjulianto S (2021) Isolation and identification of avirulent strains of Bacillus anthracis from environmental samples in Central Java, Indonesia, Int J One Health, 7(2): 204-211.

\begin{abstract}
Background and Aim: Anthrax is a non-contagious infectious disease caused by Bacillus anthracis. The bacteria form spores that are resistant to extreme conditions and can contaminate the environment for decades. This study aimed to detect and characterize B. anthracis found in endemic areas of anthrax in Yogyakarta and Central Java province, Indonesia.

Materials and Methods: Soil samples were collected from Gunungkidul regency, Yogyakarta province ( $\mathrm{n}=315)$ and Boyolali regency, Central Java province $(n=100)$. Additional soil samples $(n=10)$ and straw samples $(n=5)$ were obtained from Pati regency, Central Java province. The isolation and identification of B. anthracis were performed using conventional methods: Morphology of bacteria colony in solid media, Gram staining, capsule staining, spores staining, and motility test. Isolates were further identified using polymerase chain reaction (PCR) against Ba813, lef (pXO1), and capC (pXO2) gene. An avirulent vaccine strain of $B$. anthracis (strain $34 \mathrm{~F} 2$ ) was used as a control.
\end{abstract}

Results: Only four samples grew on blood agar with a ground-glass appearance, white-gray colony (Gunungkidul and avirulent strain) or yellowish (Boyolali and Pati). All were Gram-positive, presented chains, square-ended rods, spores, and were then identified as $B$. anthracis. Boyolali, Pati, and avirulent strain isolates had slightly different characteristics, including the growth of non-mucoid in the bicarbonate agar medium, and their uncapsulated form. The PCR showed two Gunungkidul isolates which amplified three genes, including Ba813, lef, and capC. Contrarily, the other isolates did not amplify the $\operatorname{cap} C$ gene.

Conclusion: Gunungkidul isolates were identified as virulent strains of B. anthracis while Boyolali and Pati isolates were proposed as avirulent strains. This is the first report of isolation and identification of avirulent strains of $B$. anthracis in Central Java, Indonesia.

Keywords: avirulent Bacillus anthracis, Boyolali, identification, pati, polymerase chain reaction multiplex.

\section{Introduction}

Anthrax, a non-contagious infectious disease caused by Bacillus anthracis, is classified as a neglected zoonotic disease by the World Health Organization (WHO) [1]. Anthrax mainly attacks both domestic and wild animals, mainly herbivores, and can cause death [2]. This comes with a loss to the farmers due to its high mortality rate, influencing the economic and several social factors. In addition, anthrax has the potential to be used as a bioterrorism agent [3]. The deaths in humans are due to the "spillover" of anthrax cases in animals through cutaneous, gastrointestinal/oropharyngeal, and respiration forms. The newest route of infection, injectional anthrax, is obtained through

Copyright: Apriliana, et al. This article is an open access article distributed under the terms of the Creative Commons Attribution 4.0 International License (http://creativecommons.org/licenses/ by/4.0/), which permits unrestricted use, distribution, and reproduction in any medium, provided you give appropriate credit to the original author(s) and the source, provide a link to the Creative Commons license, and indicate if changes were made. The Creative Commons Public Domain Dedication waiver (http:// creativecommons.org/ publicdomain/zero/1.0/) applies to the data made available in this article, unless otherwise stated. the contamination of anthrax spores on heroin used by drug users with symptoms of soft-tissue infection at the injection sites $[4,5]$. To date, only sporadic cases of anthrax infection have been reported, especially in African and Asian countries, as well as in some parts of Europe, America, and Australia [6].

However, anthrax incidents in Indonesia, both in animals and humans, are still frequently reported, especially in endemic areas. Recurrent or current cases are often reported, even though cases of livestock death are not reported timely. Some endemic areas were the Central Java Province, as stated in Pati regency (1990), Boyolali regency (1990 and 2011), and Special Region of Yogyakarta, especially in Gunungkidul regency (2019) [7,8]. Anthrax cases in Boyolali and Gunungkidul regency attacked not only livestock but also humans. Some people involved in slaughtering or consuming the ill livestock showed the cutaneous-type and gastrointestinal-type anthrax symptoms, which caused death [9]. One solution made in endemic areas was vaccination using the live Sterne spore vaccine (Anthravet, National Center 
for Veterinary Biologics known as Pusat Veterinaria Farma, Surabaya Indonesia) to all types of susceptible animals, such as cows, buffalos, goats, sheep, horses, and pigs [7]. Anthrax supervisory in those areas was still performed through surveillance activities. Until 2019, negative results were obtained from the environmental sample tests from Pati, Boyolali, and Gunungkidul regency [10].

Controlling anthrax is challenging since the bacteria forms spores resistant to extreme conditions such as heat, cold, decay processes, chemical substances (including disinfectants), and radiations [2,3]. Sporulation occurs when the infected animal's blood contains $B$. anthracis vegetative cells which are exposed by oxygen, forming spores $[11,12]$. Environments frequently contaminated by $B$. anthracis in endemic areas are mainly soil, water, and hays or straws [13]. B. anthracis has a high resistance range in the form of spores, yet these bacteria are sensitive to environmental conditions, such as temperature, humidity, $\mathrm{pH}$, and calcium content in the soil [2]. Environment-specific conditions, including the existing populations of other Bacillus species, influence the integrity of $B$. anthracis and possibly its phenotype and genotype $[14,15]$.

This study aimed to detect and characterize the $B$. anthracis found in environmental samples of endemic areas. The results of this research are expected to be used as a basic principle to reduce the number of anthrax cases.

\section{Materials and Methods \\ Ethical approval}

The study was conducted in accordance with the Guide for Bacillus anthracis identification $[2,16]$ recommended by the Ministry of Agriculture, Indonesia. All experiments conducted in a BSL-2 plus facilities laboratory BBVet Wates with Accreditation number: LP-618-IDN.

\section{Study period and location}

The study was conducted from July 2019 to August 2020. The study areas were Gunungkidul regency, Yogyakarta province, Boyolali regency, Central Java province, Pati regency, Central Java province. The samples were processed at the Zoonosis Laboratory of BBVet Wates, with BSL-2 plus facilities.

\section{Materials}

This research used environmental samples obtained from anthrax endemic areas: 315 soil samples from Gunungkidul regency, Special Region of Yogyakarta, 100 soil samples from Boyolali regency, Central Java Province, and 10 soil and five straw samples from Pati regency, Central Java Province (Table-1). The three areas of origin of these samples are located in one island bordering the land route where the distance between districts is Boyolali regency and Pati regency as far as $165 \mathrm{~km}$, while the distance from Boyolali regency and Gunungkidul regency is $86 \mathrm{~km}$
Table-1: Sample origin and type.

\begin{tabular}{|c|c|c|}
\hline Sample origin & $\begin{array}{l}\text { Sample } \\
\text { (Amount/Type) }\end{array}$ & Year \\
\hline $\begin{array}{l}\text { Ngrejek Wetan Hamlet, Gombang } \\
\text { Village, Ponjong District, } \\
\text { Gunungkidul Regency, Yogyakarta }\end{array}$ & 315/Soil & 2020 \\
\hline $\begin{array}{l}\text { Banyuanyar Village, Ampel District, } \\
\text { Boyolali Regency, Central Java }\end{array}$ & t,100/Soil & 2019 \\
\hline $\begin{array}{l}\text { Clangap Hamlet, Soneyan Village, } \\
\text { Margoyoso District, Pati Regency, } \\
\text { Central Java }\end{array}$ & 10/Soil 5/Straw & 2020 \\
\hline B. anthracis vaccine strain $34 \mathrm{~F} 2$ & Isol & \\
\hline Bacillus cereu & Isolate & \\
\hline
\end{tabular}

B. anthracis $=$ Bacillus anthracis

away (Figure-1). The B. anthracis vaccine strain 34F2 and Bacillus cereus ATCC 11778 (Culti-Loops ${ }^{\mathrm{TM}}$, Thermo Scientific, USA) were used as controls. The isolation and identification of infectious materials were performed in the biosafety level 2 (BSL-2) laboratory at the Disease Investigation Center (known as Balai Besar Veteriner), Wates, Special Region of Yogyakarta, Indonesia. All work was conducted in a Biosafety Cabinet class II type A2 (ESCO, Singapore) at the Zoonosis Laboratory of BBVet Wates, with BSL-2 plus facilities. Relevant PPE was used along with cuffed sleeves, safety glasses with side shields, and nitrile gloves. Bleach-based products and $70 \%$ ethanol were utilized to disinfect surfaces and equipment. All solid biohazardous waste was autoclaved before removal and incineration [2].

\section{Methods}

\section{Phenotypic test}

The presence of $B$. anthracis from samples in this research has been phenotypically confirmed based on guidelines from WHO (2008) and OIE $(2018)[2,16]$. A total of $10 \mathrm{~g}$ from five pooled samples were resuspended in $100 \mathrm{mLdistilled} \mathrm{water} \mathrm{and} \mathrm{then} \mathrm{homogenized.}$ The supernatant $(10 \mathrm{~mL})$ was taken andcentrifuged at $7500 \mathrm{x} g$ for $15 \mathrm{~min}$. To the obtained pellets were added $2 \mathrm{~mL}$ of distilled water and then mixture was incubated in a water bath with a temperature of $65^{\circ} \mathrm{C}$ for $15 \mathrm{~min}$. One inoculating needle from the suspension was fertilized in 5\% sheep blood agar (SBA) plate and incubated overnight at $37^{\circ} \mathrm{C}$. The obtained pure colony was then fertilized in $0.7 \%$ bicarbonate agar media in a desiccator and incubated at $37^{\circ} \mathrm{C}$, to induce the capsule formation and fertilization in the defibrinated sheep blood media. The motility test was conducted microscopically using the hanging-drop preparation and culture in sulfide indole motility (SIM) media to evaluate the bacteria's growth patterns. An antibiotic sensitivity test was then conducted using Kirby-Bauer's agar disk diffusion technique to the penicillin $\mathrm{G}$ antibiotics $10 \mathrm{U}$ (CT0043B) (Oxoid ${ }^{\mathrm{TM}}$, Thermo Scientific, USA) on the suspension equal to $0.5 \mathrm{McFarland}$ standards. The bacterial isolates were then stained using Gram staining - capsule staining with polychrome methylene blue (PMB) - and spore staining using Ziehl-Neelsen 
modification technique. $B$. anthracis viability test was carried out by isolating 1 ose [ 1 inoculating loop, approximately $1 \mu \mathrm{L}$ filtrate (disposable loops, Nunc ${ }^{\mathrm{TM}}$ 253287, Thermo Scientific, USA)] of the filtrate from sample preparation on SBA media. If colony growth was observed, then the isolate samples were re-inactivated before polymerase chain reaction (PCR); if the growth was negative, then the filtrate can be continued for DNA extraction.

\section{Molecular Identification}

Gene identification methodology started by extracting the bacteria's DNA as the template, in accordance with the Gram-positive bacterial extraction protocol using the Qiamp DNA Mini Kit (Qiagen, Hilden, Germany). Bacteria were inactivated by heating at $95^{\circ} \mathrm{C}$ for $15 \mathrm{~min}$, passed through a Nanosep MF (PAL) membrane, and centrifuged at $13.000 \times g$ for $3 \mathrm{~min}$ [17]. A total of $4 \mu \mathrm{L}$ DNA template was amplified using multiplex PCR with the HotStar-Taq ${ }^{\circledR}$ Master Mix Kit (Qiagen, Hilden, Germany) to the chromosomal decoding gene (Ba813), plasmid decoding gene pXO1 (lef), plasmid decoding gene $\mathrm{pXO} 2$ (capC) with the primary sequences (Table-2), and programs just like those previously used $[17,18]$. The PCR products were analyzed using a $1.5 \%$ agarose gel electrophoresis and visualized with gel documentation (AlphaImager ${ }^{\mathrm{TM}}$, Alpha Innotech, USA) after staining with SYBR ${ }^{\circledR}$ safe DNA gel stain (Invitrogen, USA). Data obtained both phenotypically and genotypically by PCR were analyzed descriptively.

\section{Results}

\section{Phenotypic diagnostic test}

To confirm if anthrax was observed in the samples collected, phenotypic characters were analyzed (Table-3). Two pooled soil samples from Gunungkidul regency and $B$. anthracis strain $34 \mathrm{~F} 2$ isolates grew in SBA media and had grayish-white color (Figure-2a). Two isolates from Boyolali and Pati had yellowish color with mucoid center (Figure-2b). All the other samples did not have suspicious colonies of $B$. anthracis. The four samples with suspicious colonies of anthrax were then subcultured. These colonies presented non-hemolytic character with a diameter size of $2-5 \mathrm{~mm}$, slightly convex-to-flat colony surface, rough dull appearance, irregular/fibrous colony at the edge (curled like hair/ medusa head appearance), and performed like beaten egg-white appearance when lifted using an inoculating needle. The control B. cereus isolates growing in SBA presented yellowish-white color, with hemolyzed character, and not sticky when the colony was lifted using the inoculating needle.

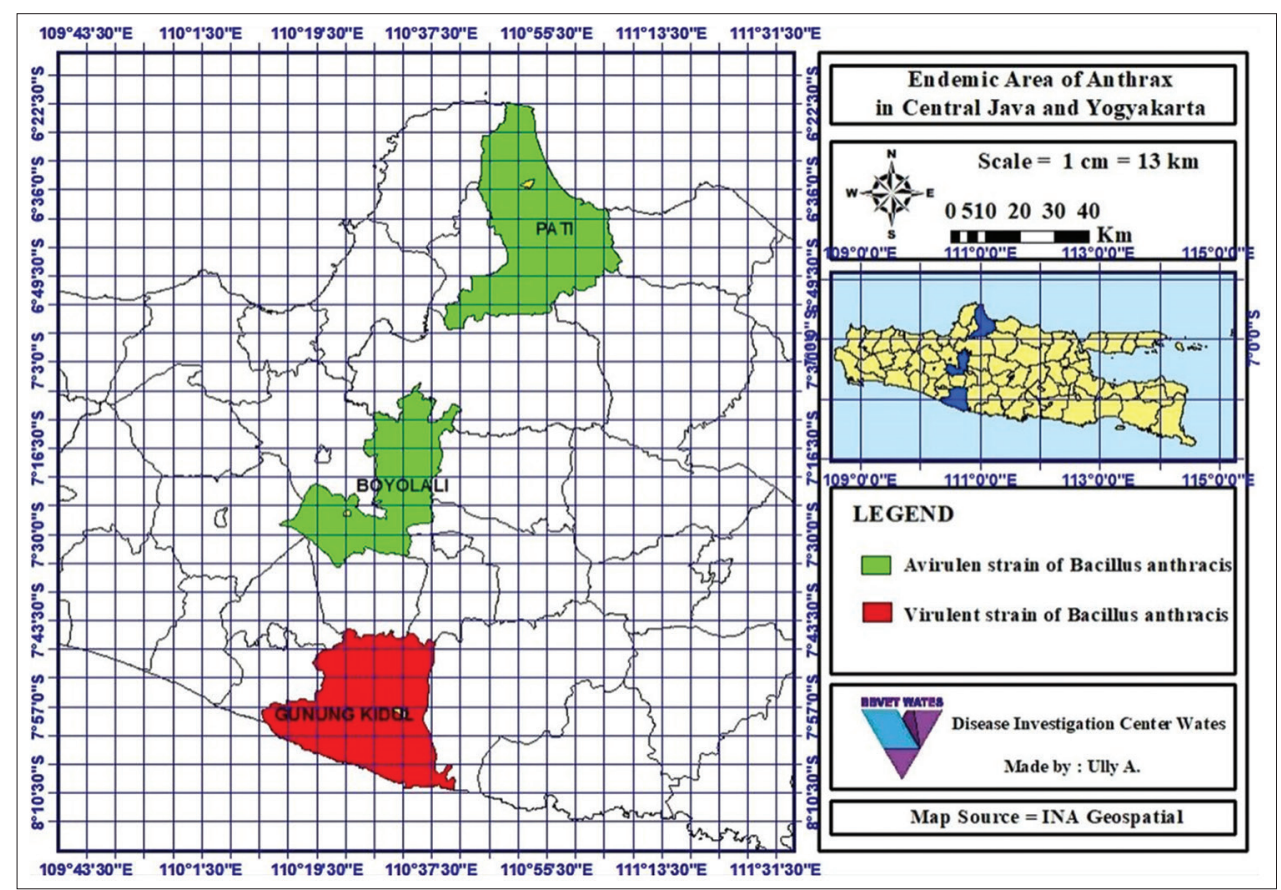

Figure-1: The location of environmental sampling in cases of livestock death is suspected of Anthrax.

Table-2: Primer Sequences on Multiplex PCR for B. anthracis identification.

\begin{tabular}{|c|c|c|c|}
\hline Primers & Sequence $\left(5^{\prime}-3^{\prime}\right)$ & Position & Length (bp) \\
\hline Rev: Ba813 R1 & 5'-TTA АTT CAC TTG CAA CTG ATG GG-3' & $227-249$ & 152 \\
\hline Fwd: Ba813 R2 & 5'-AAC GAT AGC TCC TAC ATT TGG AG-3' & $98-120$ & \\
\hline Rev: lef 3 & 5'-CTT TTG CAT ATT ATA TCG AGC-3' & $1238-1258$ & 385 \\
\hline Fwd: lef 4 & 5'-GAA TCA CGA ATA TCA ATT TGT AGC-3' & $1599-1622$ & \\
\hline Rev: $\operatorname{cap}(\mathrm{C}) 57$ & 5'-ACT CGT TTT TAA TCA GCC CG-3' & $1603-1622$ & 264 \\
\hline Fwd: $\operatorname{cap}(\mathrm{C}) 58$ & 5'-GGT AAC CCT TGT CTT TGA AT-3' & 1847-1866 & \\
\hline
\end{tabular}

$B$. anthracis=Bacillus anthracis, $\mathrm{PCR}=$ Polymerase chain reaction 
The results of the motility test in semisolid media of SIM for the four isolates showed that the growth was only observed on the formerly punctured areas (non-motile), while $B$. cereus extensively grew up to a turbid tube (motile) (Table-3). The motility test on the hanging-drop preparation obtained two isolates from Gunungkidul regency, while $B$. anthracis 34F2 seemed to be formed in chains and non-motile cell alignments. The two isolates from Boyolali and Pati seemed to

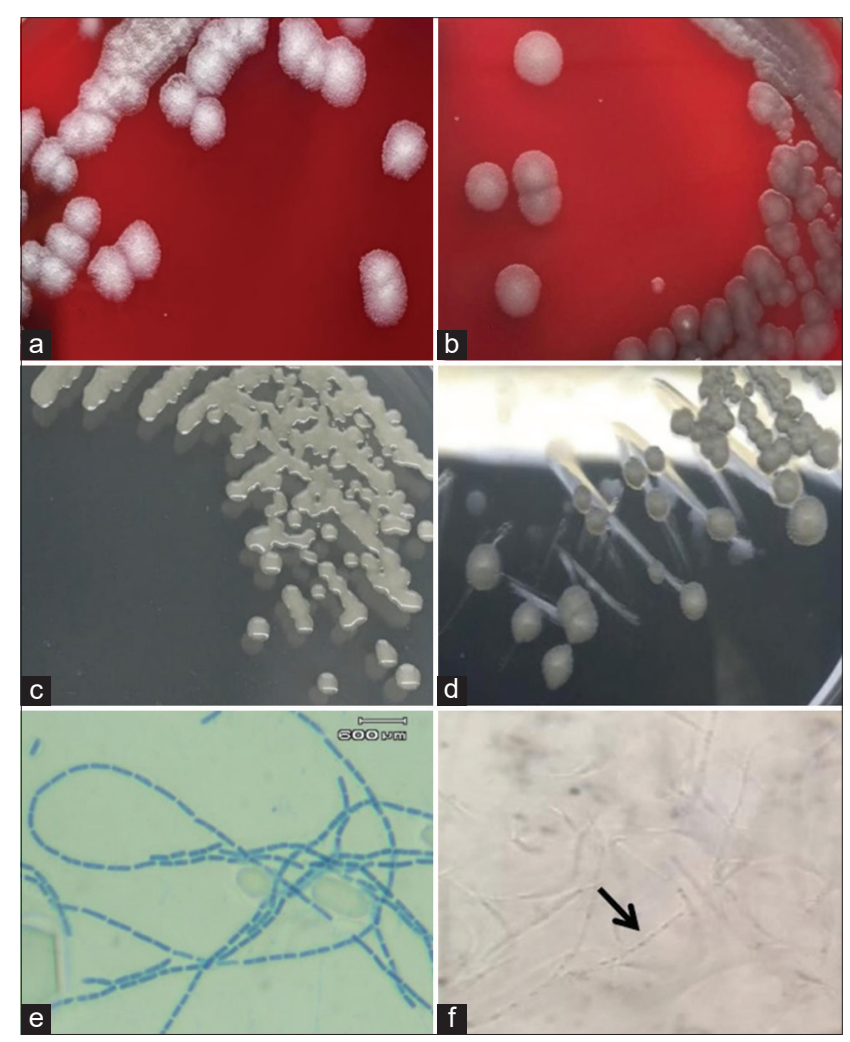

Figure-2: Morphology of bacterial colony (a-d) and morphology of bacterial isolate cells from Pati Regency (e-f). (a) Greyish-white colonies and non-hemolytic of Bacillus anthracis in the sheep blood agar (SBA) media. (b) Yellowish color colonies with mucoid center in the SBA media and non-hemolytic from Pati isolate. (c) Mucoid colonies of $B$. anthracis in Bicarbonate media. (d) The colony in non-mucoid colony in bicarbonate agar media with the protruding peak. (e). Rod-shape cells, lengthening alignment, and no capsule in the polychrome methylene blue staining. (f) Rod-shape cells (arrow), lengthening alignment, and non-motile in the hanging-drop preparation. present long-chained cells (Figure-2f), with some being small (3-5 cells) and non-motile. Conversely, $B$. cereus seemed to be fast-moving bacterial cells under the microscope $(\times 1000$ magnification $)$. All isolates from the environments and $B$. anthracis strain 34F2 showed to be sensitive to penicillin; however, B. cereus showed to be resistant (Table-3).

Gram staining examination showed that all isolates, including B. cereus were Gram-positive bacteria, rod in shape with square ends, and large in size. The bacterial cells from the isolates from Gunungkidul, Boyolali, Pati, and B. anthracis 34F2 seemed to be a series of train wagons-like length alignment (box car or bamboo stick appearance). The staining to spores showed that the isolates had the non-inflating sporangium located in the center/sub-terminal area just like $B$. anthracis $34 \mathrm{~F} 2$ isolate. Two isolates from the Gunungkidul regency presented macroscopical colonies with mucoid-like surface (Figure-2c) and microscopically the presence of the transparent capsules covered with pink color around the blue-colored cells. B. anthracis 34F2 and two samples from Boyolali and Pati presented dry and rough colonies. However, Boyolali and Pati isolates showed a slight difference from $B$. anthracis 34F2: A protruding colony surface at the center of the colony (Figure-2d), while the surface of $B$. anthracis $34 \mathrm{~F} 2$ is flat. Capsules were not found in these three colonies on microscopic examination with PMB staining (Figure-2e).

\section{Molecular test with multiplex PCR technique}

The phenotype tests were conducted using multiplex PCR technique with the virulent gene identification. Two environmental isolates from Gunungkidul amplified lef (385 bp), capC (264 bp), and Ba813 (165 bp), while the isolate from Pati, Boyolali, and B. anthracis 34F2 which used as a positive control for avirulent strain of $B$. anthracis amplified lef and Ba813, but not capC (Figure-3).

\section{Discussion}

Early diagnosis of suspected anthrax was carried out through conventional microbiological methods. Based on the growth characteristics in specific media $[15,19]$, four isolates from environmental

Table-3: Characteristics of $B$. anthracis isolates identified from environmental samples in Gunungkidul $(n=2)$, Boyolali $(n=1)$, and Pati $(n=1)$.

\begin{tabular}{|c|c|c|c|c|c|c|}
\hline \multirow{3}{*}{$\begin{array}{l}\text { Microbiological } \\
\text { characters }\end{array}$} & \multicolumn{6}{|c|}{ Result } \\
\hline & \multicolumn{3}{|c|}{ Sample } & \multicolumn{3}{|c|}{ Control } \\
\hline & Gunungkidul & Pati & Boyolali & B. anthracis & B. anthracis avirulent & Bacillus cereus \\
\hline Hemolysis & - & - & - & - & - & + \\
\hline Motility & - & - & - & - & - & + \\
\hline $\begin{array}{l}\text { Susceptibility to } \\
\text { Penicillina }\end{array}$ & $\mathrm{S}$ & $\mathrm{S}$ & $\mathrm{S}$ & $\mathrm{S}$ & $\mathrm{S}$ & $\mathrm{R}$ \\
\hline $\begin{array}{l}\text { Bicarbonate } \\
\text { mediab }^{b}\end{array}$ & Mucoid & Non-mucoid & Non-mucoid & Mucoid & Non-mucoid & Non-mucoid \\
\hline Capsule & + & - & - & + & - & - (in vitro) \\
\hline
\end{tabular}

aS=Sensitive, $\mathrm{R}=$ Resistant; $-=$ Negative; $+=$ Positive. ${ }^{\mathrm{b}}$ Capsule production in bicarbonate media and defibrinated sheep blood media. B. anthracis=Bacillus anthracis 


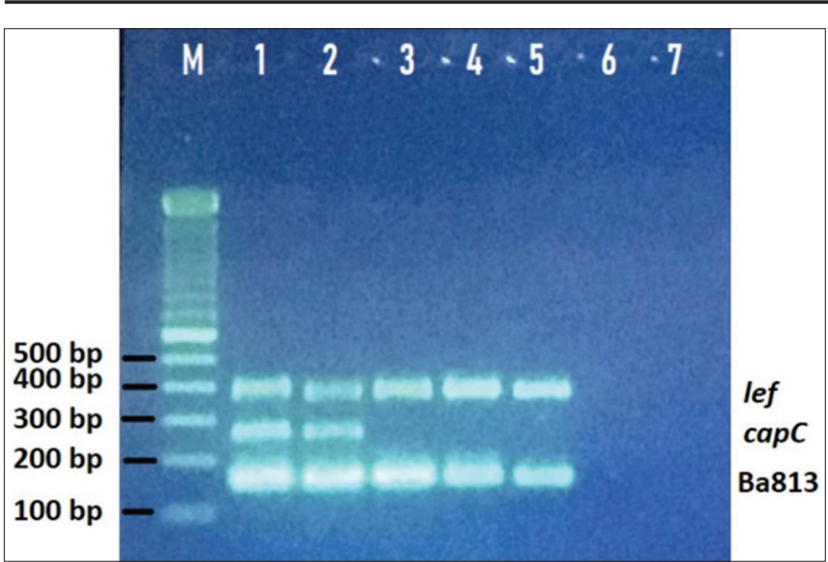

Figure-3: Molecular identification of Bacillus anthracis with multiplex polymerase chain reaction technique from the environmental samples. $M=$ standard marker; Lanes 1 and 2 are isolates from Gunungkidul, positive result of virulent $B$. anthracis strain, that is, detected DNA fragment as the chromosomal marker (Ba813, 152 bp), plasmid pXO1 (lef, 385 bp) and plasmid pXO2 (capC, 264 bp). Lane 3 (isolate from Pati), lane 4 (isolate from Boyolali), and lane 5 ( $B$. anthracis strain 34F2, as positive control) were avirulent $B$. anthracis strain which are only detected DNA fragment as the chromosomal marker (Ba813, 152 bp) and plasmid pXO1 (lef, 385 bp). Lane 6 Bacillus cereus ATCC 11778 as negative control. Lane 7 non-template control.

samples were putatively identified as B. anthracis, although the two isolates from Gunungkidul were different from the isolates from Boyolali and Pati. $B$. anthracis colonies were of grayish-white color in SBA media, with a diameter size of $2-5 \mathrm{~mm}$, flat or slightly convex, irregularly round, slightly undulate edges, ground-glass appearance, and comma-shaped projections [20]. This presumptive identification of $B$. anthracis demonstrated a lack of $\beta$-hemolysis on blood agar plates, and a rapid protocol to control the presence of those bacteria was put in place [21]. The results were similar to that of the isolates from Boyolali and Pati, as reported by Klee et al. [15], who isolated clinical samples from organs from monkeys with anthrax-like symptoms. Researchers found that the colony had a diameter size of $5 \mathrm{~mm}$, and were rough, with greenish-gray color, and mucoid central colony. However, after incubated for $48 \mathrm{~h}$, the diameter of the same colony became larger $(>10 \mathrm{~mm})$, had smooth surface, and different mucoid than B. anthracis.

The bacterial motility is one character that can be used to differentiate B. anthracis from other Bacillus species [21]. All isolates had non-motile characteristics both from SIM media and hanging-drop preparations, and were sensitive to penicillin. These results demonstrated an increased likelihood that the four environmental isolates were in fact $B$. anthracis. According to Olani et al. [22], there are some reference standards to differentiate $B$. anthracis from $B$. cereus due to the absence of $\beta$-hemolytic in SBA media, absence of phospholipase $C$ activity, lack of motility, susceptibility to penicillin, and sensitivity to the $\gamma$ bacteriophage.
The microscopic examination from Gram staining showed that all isolates, including $B$. cereus, were large rod-shaped Gram-positive bacteria, and formed spores [16,23]. Long-stranded cells are very typical in $B$. anthracis and this resembles "caput medusae" characteristic [16]. This result also strengthened the presumption that the isolates were $B$. anthracis. $B$. anthracis produce capsules arranged from the poly$\gamma$-D-glutamic acid (PDGA) polymers. These capsules can be directly seen from clinical samples using PMB staining [16]. Anthrax capsules are formed in anaerobic conditions or environments similar to temperature and bicarbonate elements similar to that of the mammal host. The in vitro capsule synthesis requires special media containing those compounds or germ isolation in the defibrinated blood or media containing serum [2,24]. Based on the result of phenotypic identification, all isolates from the environments were identified as $B$. anthracis, and the two isolates from Boyolali and Pati were possibly avirulent strains, as they did not present capsules.

The capsules of $B$. anthracis hold virulence factors as they help the bacteria to attach onto the surface of host cells while protecting them from the immune innate (antibody) system and phagocytosis [25]. The PDGA capsules are synthesized by the capsule gene operon capBCADE and decoded by the smaller-size plasmid (pXO2) in $B$. anthracis genome [26]. B. anthracis is divided into two strains: Virulent strains possessing two plasmids as the virulent factor $\mathrm{pXO} 1$ and $\mathrm{pXO} 2(\mathrm{pXO} 1+\mathrm{pXO} 2+)$ for example, B. anthracis strain Ames which is classified into clade A [27,28]; avirulent strains possess only one plasmid, pXO1 (pXO1+ pXO2-), for example, B. anthracis strain Sterne which is commonly used as a vaccine $[29,30]$, and plasmid pXO2 (pXO1- pXO2+), for example, B. anthracis strain Pasteur which is also used as a vaccine [31,32]. According to Thorkildston et al. [32] and Harrington et al. [33], there is also an avirulent anthrax strain with two plasmids (pXO1+ pXO2+), namely, B. anthracis strain Pasteur I and B. anthracis strain Carbosap.

The molecular tests confirmed the phenotype test results and proved that all isolates from the original environment were identified as B. anthracis, yet with two isolates from Pati and Boyolali with no capsules. Based on the gene ownership and in accordance with Aikembayev et al. [34], two isolates from Gunungkidul were identified as virulent $B$. anthracis and two isolates from Pati and Boyolali were likely to be avirulent strains of $B$. anthracis. This is in line with Aikembayev et al. [34], who obtained three isolates showing characters of $B$. anthracis but not a capsule in fertilized solid media. B. anthracis could have lost one or two virulent plasmids spontaneously, caused by external factors in the environment $[34,35]$. The absence of plasmids in $B$. anthracis could be the consequence of the soil-borne lifecycle, where B. anthracis could spontaneously lose the plasmid 
during the replication processes [36]. This could provide an alternative action to prevent the anthrax outbreak by conditioning the environment so that it does not serve as an "incubator" for replicated B. anthracis.

The anthrax cases in the Gunungkidul regency of the Special Region of Yogyakarta was reported in 2019 [8], while that in Pati regency first happened in 1990 and has never been reported for a period of 30 years. Different from Pati, anthrax in Boyolali regency first happened in 1990 but occurred again in 2011 [7]. Anthrax cases can occur repeatedly, as per Lewerin et al. [13]. In Sweden, the anthrax case occurred after 27 years after the first case. This condition was due to the fact that $B$. anthracis can form spores when environmental conditions are less profitable $[3,37]$, as the dormant anthrax spores are resistant to extreme environmental conditions. Anthrax is also known as a soil disease, as the spores can survive longer in the soil. If the anthrax spores are swallowed by a susceptible host, there will be germination in the host body which can cause death [12]. Recent research showed that there is an indication of $B$. anthracis replication outside the host body, but this has not been consensual in the scientific community [37]. According to Ganz et al. [38], in favorable conditions, B. anthracis can replicate as saprophyte in the plant rhizosphere and symbiotically $B$. anthracis replicates through a bacteriophage with the earthworm and amoeba found abundantly in the soil [39]. The regulation of the environment, especially soil, the main reservoir of anthrax spores, comprises factors such as soil type, humidity, $\mathrm{pH}$, ultraviolet light, and nutrient contents, such as calcium and organic matter [40,41]. Those factors can influence the population integrity in the soil and possibly cause not only evolution, but also attenuation of $B$. anthracis [37]. Thus, anthrax eradication is not easy if it does not involve all related factors.

The repeated anthrax cases and new cases in a specific area can be caused by unsuccessful preventive and controlling actions against anthrax, especially in the event of a pandemic. The disinfection of locations and abattoirs is important as well as burning the location where livestock died [42]. Proper management to remove the carcass can be performed by burying, burning, or wrapping the animal carcass with a strong disposal bag made of plastic, then label the outer part of the containers and fasten the decaying process by sunlight exposure which will damage the vegetative cells of $B$. anthracis. The last method will only be implemented if the burying and burning actions may not be performed on the anthrax-infected wild animals in the anthrax endemic areas [1]. Poor vaccination coverage is one reason why it is challenging to eradicate anthrax in Indonesia, besides the lax supervision of livestock traffics. The small-scale livestock cultivation system and animal farmers in Indonesia, who are still in the medium to low economic class, have caused animal farmers to choose to slaughter or sell their sick or soonto-die livestock, without reporting their livestock cases to the local animal officials. Similar cases had happened in Monduli Tanzania and Bangladesh $[42,43]$, which caused an increased number of livestock deaths in the field when compared to the reported ones [44].

Anthrax is a disease agent which has a close reciprocal relationship with humans, animals, and environments [1]. One health concept is greatly required in handling anthrax in an area with cross-sectorial commitment, including in the field of animal health function, human health function, quarantine, regional officials ranging from the regional head to the village/hamlet officials, police, municipal police, disaster management agency for the disease/zoonotic pandemic, and all people in related areas. Besides, routine vaccination each year, preventing and controlling anthrax were also made through the structured surveillance activities, medication to the ill animals, quarantine actions, supervisions to the livestock traffics, issuance of health statement letter for livestock that will be traded, carcass disposal management caused by anthrax, and education to communities at risk [7,42].

The identification of two anthrax isolates from the soil sample in Pati and from the straw sample in Boyolali, which have no capsules, was greatly interesting. Thus, further molecular identification, including DNA sequencing orders is necessary. Both avirulent strains may provide new benefits on changing the environment toward shifting colonies of virulent $B$. anthracis to avirulent forms.

\section{Conclusion}

B. anthracis can be isolated and identified from soil and straw samples from anthrax endemic areas, even from cases that occurred in the past 2-10 years. B. anthracis derived from the soil samples of Boyolali and straw samples from Pati, Central Java, may be the first avirulent $B$. anthracis strain to be found in anthrax endemic areas in Java, Island. Further research should be conducted to find out whether the plasmid pXO2 virulence factor is completely lost (experiencing attenuation) or only experiencing damage in the capsule-encoding genes. In this case, the capC gene expression is greatly reduced. DNA sequencing of both $B$. anthracis avirulent strain isolates can explain its status.

\section{Authors' Contributions}

UA: Investigation and data collection, data analysis and interpretation, and drafted the manuscript. SI: Research conceptualization, supervision, review, and editing. HW and ER: Sample design and methodology. TU: Review and editing. HW: Review and editing. All authors read and approved the final manuscript.

\section{Acknowledgments}

The authors are thankful to Agricultural Human Resources Extension and Development Agency of Ministry of Agriculture of Indonesia, Directorate General of Livestock and Animal Health Services 
of Ministry of Agriculture of Indonesia and Disease Investigation Center Wates Yogyakarta, Indonesia. The authors are also thankful to Universitas Gadjah Mada, Indonesia, for funding support (3143/UN1.P.III/ DIT-LIT/PT/2021).

\section{Competing Interests}

The authors declare that they have no competing interests.

\section{Publisher's Note}

Veterinary World (Publisher of International Journal of One Health) remains neutral with regard to jurisdictional claims in published map and institutional affiliation.

\section{References}

1. Kock, R., Haider, N., Mboera, L.E. and Zumla, A. (2019) A one-health lens for anthrax. Lancet Planet Health, 3(7): e285-e286.

2. World Health Organization. (2008) Anthrax in Humans and Animals. $4^{\text {th }}$ ed. World Health Organization, Geneva. Available from: http://www.apps.who.int/iris/bitstr eam/10665/97503/1/9789241547536_eng.pdf. Retrieved on 12-02-2021.

3. Goel, A.K. (2015) Anthrax: A disease of biowarfare and public health importance. World J. Clin. Cases, 3(1): 20-33.

4. Hicks, C.W., Sweeney, D.A., Cui, X., Li, Y. and Eichacker, P.Q. (2012) An overview of anthrax infection including the recently identified form of disease in injection drug users. Intensive Care Med., 38(7): 1092-1104.

5. Shadomy, S., El Idrissi, A., Raizman, E., Bruni, M., Palamara, E., Pittiglio, C. and Lubroth, J. (2016) Anthrax Outbreaks: A Warning for Improved Prevention, Control and Heightened Awareness. Food and Agriculture Organization of the United Nations (FAO), Empres Watch, Rome, Italy. Available from: http://www.fao.org/3/i6124e/i6124e.pdf. Retrieved on 12-02-2021.

6. Carlson, C.J., Kracalik, I.T., Ross, N., Alexander, K.A., Hugh-Jones, M.E., Fegan, M., Elkin, B.T., Epp, T., Shury, T.K., Zhang, W., Bagirova, M., Getz, W.M. and Blackburn, J.K. (2019) The global distribution of Bacillus anthracis and associated anthrax risk to humans, livestock and wildlife. Nat Microbiol., 4(8): 1337-1343.

7. Ditjen, P.K.H. (2016) Pedoman Pengendalian Dan Pemberantasan Penyakit Hewan Menular (PHM): Seri Penyakit Anthrax, Kementerian Pertanian Republik Indonesia. Direktorat Jenderal Peternakan dan Kesehatan Hewan, Jakarta, Indonesia.

8. Ruhiat, E., Susanta, D.H., Wibawa, H., Poermadjaja, B., Handoko, A., Ludiro, A., Setiani, N. and dan Nugraha, D.A. (2020) Investigasi kematian ternak akibat antraks di kecamatan Ponjong kabupaten Gunungkidul Januari 2020. Pros. Ratekpil Kementerian Pertanian, 5(5): 164-174.

9. Redhono, D., Kusumawardani, A. and Dirgahayu, P. (2018) A comparison of the immune response between early exposed and 1 year post exposure to Bacillus anthracis in Indonesia. IOP Conf. Ser. Earth Environ. Sci., 125(3): 012012 .

10. Ruhiat, E., Suhardi, S., Farhani, N., Handoko, A., Mariyono, M. and dan Subekti, W. (2019) Proporsi dan distribusi penyakit antraks di Jawa Timur, Jawa Tengah, dan Yogyakarta tahun 2013-2017, Pros. Ratekpil Kementerian Pertanian, 1(9): 30-37.

11. Swick, M.C., Koehler, T.M. and Driks, A. (2016) Surviving between hosts: Sporulation and transmission. Microbiol. Spectr., 4(4): 29.

12. Finke, E.J., Beyer, W., Loderstädt, U. and Frickmann, H.
(2020) Review: The risk of contracting anthrax from spore-contaminated soil - a military medical perspective. Eur. J. Microbiol. Immunol., 10(2): 29-63.

13. Lewerin, S.S., Elvander, M., Westermark, T., Hartzell, L.N., Norström, A.K., Ehrs, S., Knutsson, R., Englund, S., Andersson, A.C., Granberg, M., Bäckman, S., Wikström, P. and Sandstedt, K. (2010) Anthrax outbreak in a Swedish beef cattle herd- $1^{\text {st }}$ case in 27 years: Case report. Acta Vet. Scand., 52(1): 7.

14. Liang, X. and Yu, D. (1999) Identification of Bacillus anthracis strains in China. J. Appl. Microbiol., 87(2): 200-203.

15. Klee, S.R., Ozel, M., Appel, B., Boesch, C., Ellerbrok, H., Jacob, D., Holland, G., Leendertz, F.H., Pauli, G., Grunow, R. and Nattermann, H. (2006) Characterization of Bacillus anthracis-like Bacteria isolated from wild great apes from Cote d'Ivoire and Cameroon. J. Bacteriol., 188(15): 5333-5344.

16. OIE. (2018) Anthrax in Terrestrial Manual. Section 2.1. Multiple Species. Ch. 2.1.1. Office International Des Epizooties, OIE, Paris, France, p1-10. Available from: https://www.oie.int/fileadmin/Home/eng/Health_standards/ tahm/3.01.01_ANTHRAX.pdf Retrieved on 12-02-2021.

17. Juwita, S., Purwanta, P., Muflihanah, M. and Djatmikowati, T.F. (2018) Identification of anthrax in endemic areas in South Sulawesi province. J. Indones. Vet. Res., 2(2): 50-55.

18. Ramisse, V., Patra, G., Garrigue, H., Guesdon, J.L. and Mock, M. (1996) Identification and characterization of Bacillus anthracis by multiplex PCR analysis of sequences on plasmids pXO1 and pXO2 and chromosomal DNA. FEMS Microbiol. Lett., 145(1): 9-16.

19. Koehler, T.M. (2009) Bacillus anthracis physiology and genetics. Mol. Aspect Med., 30(6): 386-396.

20. CDC (2002) Basic Diagnostic Testing Protocols for Level a Laboratories for the Presumptive Identification of Bacillus anthracis. Environmental Protection Agency, U. (n.d.). CDC, ASM, APHL, United States. p1-22. Available from: https:/www.epa.gov/sites/production/files/2015-07/documents/cdc-anthrax.pdf. Retrieved on 12-02-2021.

21. Zasada, A.A. (2020) Detection and identification of Bacillus anthracis: From conventional to molecular microbiology methods. Microorganisms, 8(1): 125

22. Olani, A., Dawo, F. and Lakew, M. (2020) Laboratory diagnostic methods and reported outbreaks of anthrax in Ethiopia. Eur. J. Biol. Res., 10(2): 81-95.

23. Radmehr, B., Zaferanloo, B., Tran, T., Beale, D.J. and Palombo, E.A. (2020) Prevalence and characteristics of Bacillus cereus group isolated from raw and pasteurised milk. Curr. Microbiol., 77(10): 3065-3075.

24. Misgie, F., Atnaf, A. and Surafel, K. (2015) A review on anthrax and its public health and economic importance. Acad. J. Anim. Dis., 4(3): 196-204.

25. Liu, S., Moayeri, M. and Leppla, S.H. (2014) Anthrax lethal and edema toxins in anthrax pathogenesis. Trends Microbiol., 22(6): 317-325.

26. Brézillon, C., Haustant, M., Dupke, S., Corre, J.P., Lander, A., Franz, T., Monot, M., Couture-Tosi, E., Jouvion, G., Leendertz, F.H., Grunow, R., Mock, M.E., Klee, S.R. and Goossens, P.L. (2015) Capsules, toxins and AtxA as virulence factors of emerging Bacillus cereus biovar anthracis. PLoS Negl. Trop. Dis., 9(4): e0003455.

27. Antwerpen, M.H., Sahl, J.W., Birdsell, D., Pearson, T., Pearce, M.J., Redmond, C., Meyer, H. and Keim, P.S. (2017) Unexpected relations of historical anthrax strain. MBio, 8(2): e00440-17.

28. Sahl, J.W., Pearson, T., Okinaka, R., Schupp, J.M., Gillece, J.D., Heaton, H., Birdsell, D., Hepp, C., Fofanov, V., Noseda, R., Fasanella, A., Hoffmaster, A., Wagner, D.M. and Keim, P. (2016) A Bacillus anthracis genome sequence from the Sverdlovsk 1979 autopsy specimens. MBio, 7(5): e01501-16.

29. Staab, A., Plaut, R.D., Pratt, C., Lovett, S.P., Wiley, M.R., 
Biggs, T.D., Bernhards, R.C., Beck, L.C., Palacios, G.F., Stibitz, S., Jones, K.L., Goodwin, B.G., Smith, M.A. and Sozhamannan, S. (2017) Whole-genome sequences of variants of Bacillus anthracis sterne and their toxin gene deletion mutants. Genome Announc., 5(45): e01231-17.

30. Ehling-Schulz, M., Lereclus, D. and Koehler, T.M. (2019) The Bacillus cereus Group: Bacillus species with pathogenic potential. Microbiol. Spectr., 7(3): 32.

31. Liang, X., Zhang, H., Zhang, E., Wei, J., Li, W., Wang, B., Dong, S. and Zhu, J. (2016) Identification of the pXO1 plasmid in attenuated Bacillus anthracis vaccine strains. Virulence, 7(5): 578-586.

32. Thorkildson, P., Kinney, H.L. and AuCoin, D.P. (2016) Pasteur revisited: An unexpected finding in Bacillus anthracis vaccine strains. Virulence, 7(5): 506-507.

33. Harrington, R., Ondov, B.D., Radune, D., Friss, M.B., Klubnik, J., Diviak, L., Hnath, J., Cendrowski, S.R., Blank, T.E., Karaolis, D., Friedlander, A.M., Burans, J.P., Rosovitz, M.J., Treangen, T., Phillippy, A.M. and Bergman, N.H. (2013) Genome sequence of the attenuated carbosap vaccine strain of Bacillus anthracis. Genome Announc., 1(1): e00067-12.

34. Aikembayev, A.M., Lukhnova, L., Temiraliyeva, G., MekaMechenko, T., Pazylov, Y., Zakaryan, S., Denissov, G., Easterday, W.R., Van Ert, M.N., Keim, P., Francesconi, S.C., Blackburn, J.K., Hugh-Jones, M. and Hadfield, T. (2010) Historical distribution and molecular diversity of Bacillus anthracis, Kazakhstan. Emerg. Infect. Dis., 16(5): 789-796.

35. Cooper, C., Buyuk, F., Schelkle, B., Saglam, A.G., Celik, E., Celebi, O., Sahin, M., Hawkyard, T. and Baillie, L. (2017) Virulence plasmid stability in environmentally occurring Bacillus anthracis from North East Turkey. Antonie Van. Leeuwenhoek, 110(1): 167-170.

36. Braun, P., Grass, G., Aceti, A., Serrecchia, L., Affuso, A., Marino, L., Grimaldi, S., Pagano, S., Hanczaruk, M., Georgi, E., Northoff, B., Schöler, A., Schloter, M., Antwerpen, M. and Fasanella, A. (2015) Microevolution of anthrax from a young ancestor (M.A.Y.A.) suggests a soilborne life cycle of Bacillus anthracis. PLoS One, 10(8): e0135346.

37. Carlson, C.J., Getz, W.M., Kausrud, K.L., Cizauskas, C.A., Blackburn, J.K., Bustos Carrillo, F.A., Colwell, R., Easterday, W.R., Ganz, H.H., Kamath, P.L., Økstad, O.A., Turner, W.C., Kolstø, A.B. and Stenseth, N.C. (2018) Spores and soil from six sides: Interdisciplinarity and the environmental biology of anthrax (Bacillus anthracis). Biol. Rev. Camb. Philos. Soc., 93(4): 1813-1831.

38. Ganz, H.H., Turner, W.C., Brodie, E.L., Kusters, M., Shi, Y., Sibanda, H., Torok, T. and Getz, W.M. (2014) Interactions between Bacillus anthracis and plants may promote anthrax transmission. PLoS Negl. Trop. Dis., 8(6): e2903.

39. Dey, R., Hoffman, P.S. and Glomski, I.J. (2012) Germination and amplification of anthrax spores by soil-dwelling amoebas. Appl. Environ. Microbiol., 78(22): 8075-8081.

40. Driciru, M., Rwego, I.B., Ndimuligo, S.A., Travis, D.A., Mwakapeje, E.R., Craft, M., Asiimwe, B., Alvarez, J., Ayebare, S. and Pelican, K. (2020) Environmental determinants influencing anthrax distribution in Queen Elizabeth Protected Area, Western Uganda. PLoS One, 15(8): e0237223.

41. Nicholson, W.L. and Galeano, B. (2003) UV resistance of Bacillus anthracis spores revisited: Validation of Bacillus subtilis spores as UV surrogates for spores of $B$. anthracis Sterne. Appl. Environ. Microbiol., 69(2): 1327-1330.

42. Mwakapeje, E.R., Høgset, S., Fyumagwa, R., Nonga, H.E., Mdegela, R.H. and Skjerve, E. (2018) Anthrax outbreaks in the humans-livestock and wildlife interface areas of Northern Tanzania: A retrospective record review 20062016. BMC Publ. Health, 18(1): 106.

43. Rume, F.I., Karim, M.R., Ahsan, C.R., Yasmin, M. and Biswas, P.K. (2020) Risk factors for bovine anthrax in Bangladesh, 2010-2014: A case-control study. Epidemiol. Infect., 148: e67.

44. Coffin, J.L., Monje, F., Asiimwe-Karimu, G., Amuguni, H.J. and Odoch, T. (2015) A one health, participatory epidemiology assessment of anthrax (Bacillus anthracis) management in Western Uganda. Soc. Sci. Med., 129: 44-50.

$* * * * * * * *$ 